\title{
Technological development of sustainable maize production and its effect on yield stability
}

\author{
MIHÁLY SÁRVÁRI
}

University of Debrecen, Faculty of Agricultural and Food Sciences and Environmental Management, Institute of Crop Sciences, Debrecen, Hungary sarvari@agr.unideb.hu

\section{Summary}

In 2015 and 2016, we examined the effect of NPK nutrients, sowing date and plant density on yield on typical meadow soil. The amount of precipitation was $282.0 \mathrm{~mm}$ in 2015 (January-September), $706.0 \mathrm{~mm}$ in 2016 and the 30-year average is $445.8 \mathrm{~mm}$.

Agrotechnical factors:

- Experiment a)

5 Dow AgroSciences hybrid with three sowing dates and three plant densities

\section{- Experiment b)}

In 2015 eight, in 2016 ten hybrids with different genetic characteristics and growing seasons, with control (without fertilization), $\mathrm{N}_{80}+\mathrm{PK}$ and $\mathrm{N}_{160}+$ PKtreatments, five plant densities (50-90 thousand) with 10 thousand plants difference between the different densities.

In a drought year, we reached the higher yield in the earlier sowing date and with the lower lower plant density of 70 thousand plants ha-1-. The maximum yield, depending on the agrotechnical factors, was 10-12 t ha-1 in 2015, while in 2016 it was $14-16 \mathrm{t} \mathrm{ha}^{-1}$. Yield stability can be increased using hybrid-specific cultivation techniques.

Keywords: sowing date, fertilizer dosage, plant number, hybrid

\section{Introduction}

In Hungary, $89 \%$ of grain maize is used as forage crop (Széles and Nagy, 2003), but it can be variously used, which is confirmed by the fact that its industrial processing is also dynamically developing, e.g. in the production of bioethanol, vegetable oil, invert sugar, alcohol etc. (Pepó and Sárvári, 2011).

In the decade between 1970 and 1980, Hungary was a world leader in maize production. According to its yield per unit area it was ranked third in the world, and in terms of genetic progress - with a yield increase of $151.5 \mathrm{~kg} \mathrm{ha}^{-1}$ between 1960 and 1981 - it occupied the first place (Menyhért, 1985). 
The emergence of modern biological bases (maize hybrids), the development of the technical background, the increase in the usage of chemicals (Debreczeniné, 1994) as well as the greater expertise, have had a determining role in the increase of the average yield.

One of the essential preconditions of maize production is to select the biological bases correctly (Pepó and Pepó, 1993). More recently, as a result of the appropriate work of breeders, the nutrient digestion and utilization capability of hybrids and their response to fertilizers have improved (Marton et al., 2005).

There is a correlation between the sowing date and the yield, and there is an especially close, significant correlation between the sowing date and the grain moisture content at harvest (Sárvári, 1999). In case of an earlier sowing - using good-quality seeds - a more stable and higher yield can be expected than that with the usual or later sowing date (Futó, 2003).

Increase in the yield is the highest when each of the key factors of plant production is optimal (Nagy, 2010). Maize has high productivity, but it is sensitive to the agroecological and agrotechnical conditions (Pepó et al., 2006). Based on the results, the contribution of varieties in reaching a higher yield is 26\% (Berzsenyi és Győrffy, 1995). In droughty years, with later sowing dates even a $30-40 \%$ decrease in the yield can be detected compared to early sowings (Berzsenyi and Lap, 2001). Late sowing had an unfavourable effect on the dry matter accumulation (Berzsenyi et al., 1998). The nutrient supply also influences the photosynthetic activity of maize hybrids (Csajbók et al., 2005).

The producer is interested in the plant density with which he can produce the highest yield (Bodnár, 1982). The effective and environmentally friendly maize production can be carried out only with hybrid-specific technologies (Jakab, 2003).

\section{Material and methods}

The experiment was conducted on typical meadow soil. Its liquid limit according to Arany is 52, its humus content is $42 \%$, its $\mathrm{pH}_{\mathrm{KCl}}$ is 6.4 . Its AL-soluble $\mathrm{P}_{2} \mathrm{O}_{5}$ content is $180, \mathrm{~K}_{2} \mathrm{O}$ content is $160 \mathrm{mg} \mathrm{kg}^{-1}$. The water level of the subsoil is $2-2.5$ meter. This soil is difficult to cultivate, the fixation of potassium and its incorporation into the crystal lattice is significant.

The weather in the years of the experiment 2015 was an extremely droughty year with an unfavourable precipitation pattern. The 30-year average of precipitation (January-September) is $445.8 \mathrm{~mm}$, the amount of actual rainfall was $282.0 \mathrm{~mm}-163.8 \mathrm{~mm}$ less 
than the average of many years. The 30-year average of temperature (January-September) is $11.5^{\circ} \mathrm{C}$, and that of 2015 was $1.7^{\circ} \mathrm{C}$ higher.

The weather in 2016 was favourable for maize. The amount of rainfall (January-September) was $260.2 \mathrm{~mm}$ more than the average of many years, with a remarkably good pattern. The temperature was $1.4{ }^{\circ} \mathrm{C}$ higher than the average of many years. From May to September the amount of rainfall exceeded the 30-year average in each month.

The applied agricultural techniques

We examined the yield increasing effect of nutrient supply, the sowing date and the plant density in two types of experiment.

a. type of experiment

Previous cropping: maize; nutrient supply: uniformly $\mathrm{N} 120, \mathrm{P}_{2} \mathrm{O}_{5} 80$, $\mathrm{K}_{2} \mathrm{O} 110 \mathrm{~kg} \mathrm{ha}^{-1}$ efficient fertilizer agent.

Plot size: net $22.8 \mathrm{~m}^{2}$

Sowing dates: I. 14.04 .2015 I. 06.04 .2016

II. 27. 04. 2015 II. 19.04. 2016

III. 12. 05. 2015 III. 10. 05. 2016

Plant density: 50, 70, 85 thousand plants ha ${ }^{-1}$

Soil desinfection: Force $1.5 \mathrm{G} 12 \mathrm{~kg} \mathrm{ha}^{-1}$

Chemical weed control: 2.21 ha $^{-1}$ Laudis

Harvesting: on 25. 10. 2015 and 10. 10. 2016 by Sampo combine harvester.

b. type of experiment

Previous cropping: maize

Nutrient supply: treatment \#1: control (without fertilization) treatment \#2: $\mathrm{N} 80, \mathrm{P}_{2} \mathrm{O}_{5} 50, \mathrm{~K}_{2} \mathrm{O} 60$

treatment \#3: $\mathrm{N} 160, \mathrm{P}_{2} \mathrm{O}_{5}$ 100, $\mathrm{K}_{2} \mathrm{O} 120 \mathrm{~kg} \mathrm{ha}^{-1}$ efficient

Plot size: gross $38 \mathrm{~m}^{2}$ fertilizer agent

Sowing dates: 17. 04. 2015 and 01. 04. 2016

Plant density: 50, 60, 70, 80, 90 thousand plants ha-1

Soil desinfection: Force $1.5 \mathrm{G} 12 \mathrm{~kg} \mathrm{ha}^{-1}$

Chemical weed control: 2.21 ha $^{-1}$ Laudis

Harvesting: on 25. 10. 2015 by Sampo combine harvester, on 29. 09. 2016 by hand, with cob.

Experiments have been evaluated by analysis of variance and parabolic regression analysis. 


\section{Results and discussion}

Results of the experiment in 2015

a. type of experiment

The effect of the sowing date and the plant density on the yield results showed a close correlation with the unfavourable weather conditions.

Yields produced by hybrids DS 1304 C and DS 10716 was higher in the $2^{\text {nd }}$ sowing date with the sowing date of 27.04: 10 and $11.8 \mathrm{tha}^{-1}$. This can be associated with the poor cold tolerance of the two hybrids during germination. However, the yields of the other three tested hybrids were higher in the $1^{\text {st }}$ sowing date: hybrid DS 0791 produced $11.51 \mathrm{t} \mathrm{ha}^{-1}$, hybrid DS 1310 produced $12.25 \mathrm{t} \mathrm{ha}^{-1}$, while hybrid DA Sonka reached a yield of $11.84 \mathrm{t} \mathrm{ha}^{-1}$.

In the $3^{\text {rd }}$ sowing date (12.05), the yield of the hybrids reached a considerably low level, between 6.8 and $8.0 \mathrm{t} \mathrm{ha}^{-1}$, since the time of flowering and grain filling fell in a droughty period (Figure 1).

Figure 1. The effect of the sowing date on the yield of the hybrids, in the average of plant densities (Görbeháza, 2015)

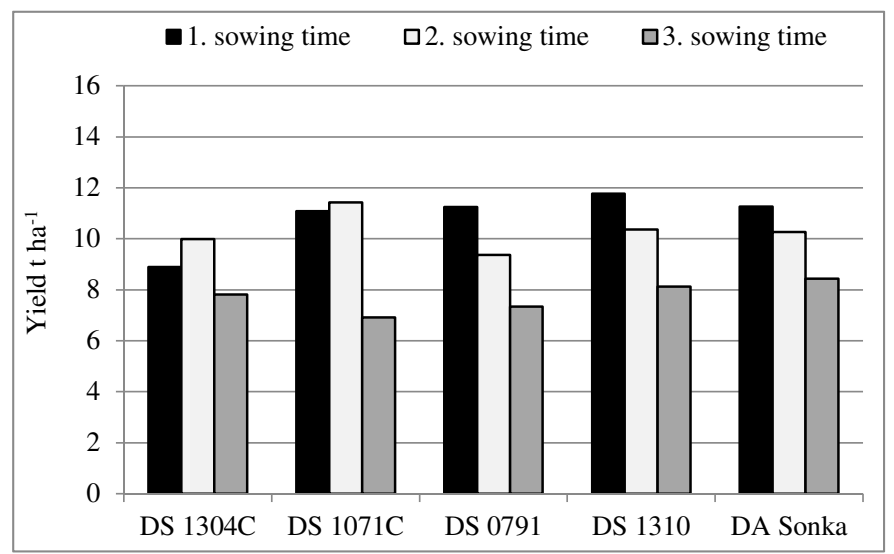

Note: LSD ${ }_{5 \%}$ Hybrid: $0.41 \mathrm{t} \mathrm{ha}^{-1}$; Sowing date: $0.32 \mathrm{t} \mathrm{ha}^{-1}$; Interaction: $1.00 \mathrm{t} \mathrm{ha}^{-1}$

The optimum plant density (from 55, 70, 85 thousand plants ha-1): each hybrid reached the yield of nearly 9-10.5 $\mathrm{t} \mathrm{ha}^{-1}$ with 70 thousand plants ha-1. The 85 thousand plants ha-1, due to lack of water, resulted in yield depression (Figure 2).

The grain moisture contents at harvest:

- $1^{\text {st }}$ sowing date: $19.90-21.30 \%$,

- $2^{\text {nd }}$ sowing date: $18.37-21.07 \%$,

- $3^{\text {rd }}$ sowing date: $20.33-22.87 \%$. 
Figure 2. The effect of the sowing date on the yield of the hybrids, in the average of the sowing dates (Görbeháza, 2015)

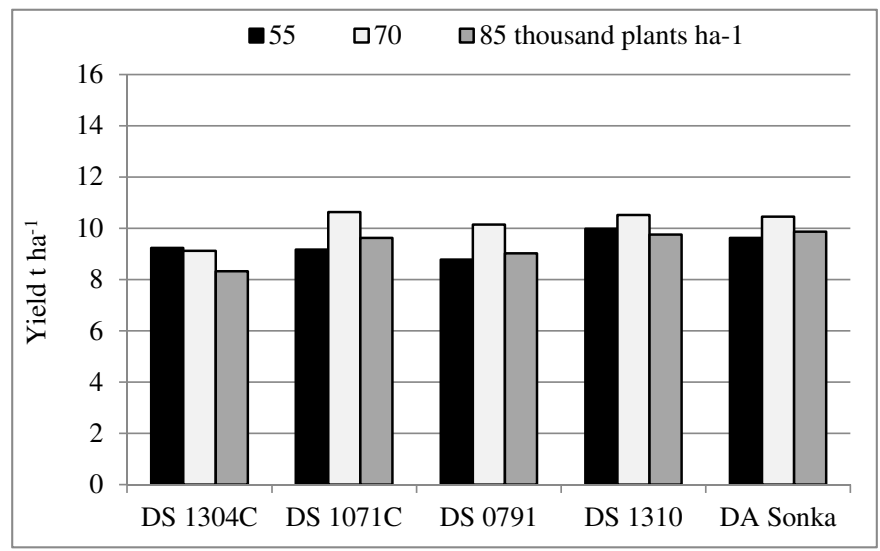

Note: $\mathrm{LSD}_{5 \%}$ Hybrid: $0.52 \mathrm{t} \mathrm{ha}^{-1}$; Sowing date: $0.40 \mathrm{t} \mathrm{ha}^{-1}$; Interaction: $0.90 \mathrm{t}$ ha-1

\section{b. type of experiment:}

Due to the remarkably extreme weather in 2015, the maize hybrids produced higher yields with $\mathrm{N} 80, \mathrm{P}_{2} \mathrm{O}_{5} 50, \mathrm{~K}_{2} \mathrm{O} 60 \mathrm{~kg}^{-1}$ effective fertilizer agents. The lowest yield was produced by hybrid Renfor, while the highest (nearly $12 \mathrm{t} \mathrm{ha}^{-1}-\mathrm{t}$ ) was reached by hybrid DKC 5141 (FAO 460) (Figure 3).

Figure 3. The effect of fertilization on the yield of the hybrids, in the average of the plant densities (Görbeháza, 2015)

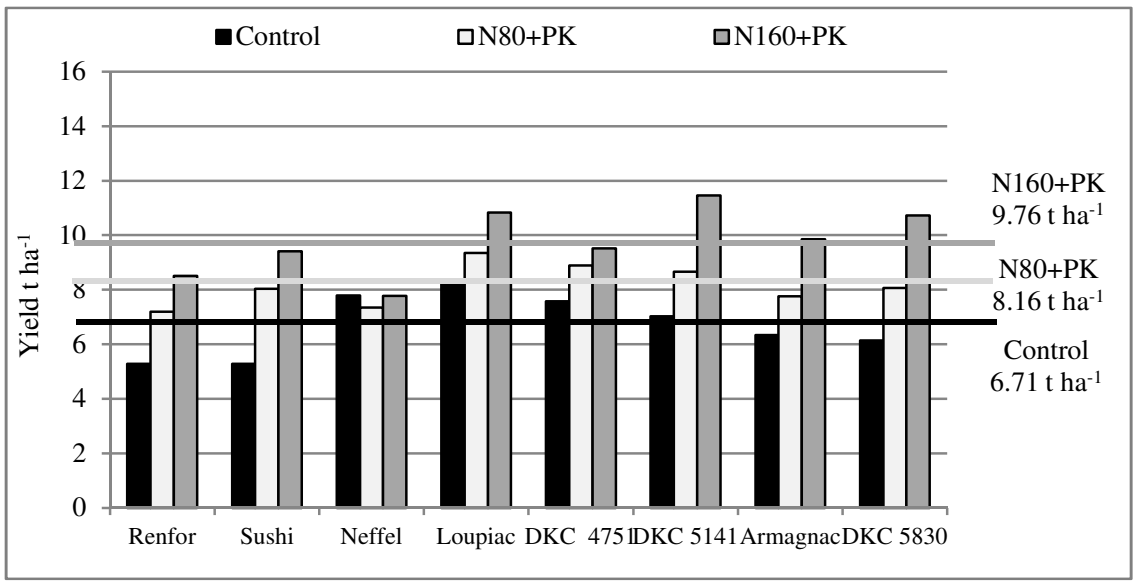

Note: $\mathrm{LSD}_{5 \%}$ Hybrid: $0.34 \mathrm{t} \mathrm{ha}^{-1}$; Sowing date: $0.21 \mathrm{t} \mathrm{ha}^{-1}$; Interaction: $0.83 \mathrm{t} \mathrm{ha}^{-1}$ 
In this droughty year, though on different yield levels, the maximum of 70 thousand plants ha-1 proved to be the optimum for the hybrids with different growing seasons.

\section{Results of the experiment in 2016}

\section{a. type of experiment}

The weather in 2016 was remarkably favourable; in the period critical for maize (flowering, grain filling) the amount of precipitation (mm) exceeded the average of many years.

Most of the hybrids achieved the higher average yield of 13-14.5 t ha-1 in the $3^{\text {rd }}$ sowing date (19. 04.-10. 05). Hybrid DS 1825 produced its maximum yield of $14.5 \mathrm{t} \mathrm{ha}^{-1}$ in the $2^{\text {nd }}$ sowing date (Figure 4).

Figure 4. The effect of the sowing date on the yield of the hybrids, in the average of the plant densities (Görbeháza, 2016)

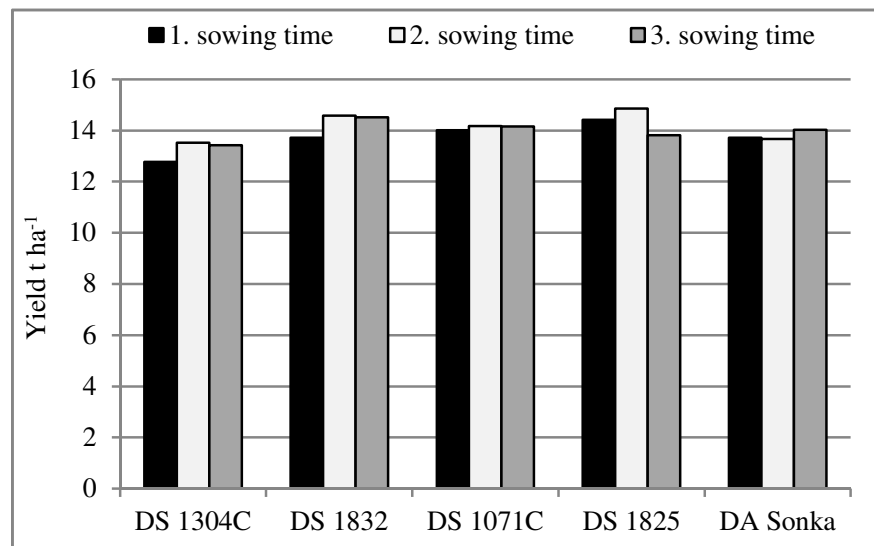

Note: LSD $5 \%$ Hybrid: 0.36 t ha $^{-1}$; Sowing date: 0.28 t ha $^{-1}$; Interaction: $0.87 \mathrm{t} \mathrm{ha}^{-1}$

The close correlation between the plant density and the yield is clearly demonstrated by the fact, that except for hybrid DS 1825, each hybrid achieved the maximum yield of cca. $14 \mathrm{t} \mathrm{ha}^{-1}$ with the higher -85 thousand plants ha-1 - plant density.

Grain moisture content at harvest:

- $1^{\text {st }}$ sowing date: $13.87-17.27 \%, 15.55 \%$ in average;

- $2^{\text {nd }}$ sowing date: $15.07-18.40 \%, 16.74 \%$ in average;

- $3^{\text {rd }}$ sowing date: $21.53-22.53 \%, 22.03 \%$ in average.

It can be concluded that in a droughty crop year the earlier sowing date and the lower plant density (of 70 thousand plants per hectare) are appropriate, while in a more favourable crop year the hybrids produced 
better yields in the $2^{\text {nd }}$ and $3^{\text {rd }}$ sowing dates $(19.04,10.05)$ with the higher plant density (of 85 thousand plants per hectare).

Based on the results, it can be established that, the yield is determined, besides the growing conditions and the crop year, by the level of water and the nutrient supply.

b. type of experiment

In a favourable crop year, the correlation between the amount of precipitation and the NPK nutrient supply is close. The yield with the control treatment (without fertilization), in the average of the hybrids, was $9.03 \mathrm{t} \mathrm{ha}^{-1}$. Hybrid Sushi had the best nutrient digestion and utilization capability, it produced a yield of nearly $11 \mathrm{t} \mathrm{ha}^{-1}$, even without fertilization. With $\mathrm{N} 80, \mathrm{P}_{2} \mathrm{O}_{5} 50, \mathrm{~K}_{2} \mathrm{O} 60 \mathrm{~kg} \mathrm{ha}^{-1}$ fertilizer treatment, the yield, in the average of the hybrids, is $13.40 \mathrm{t} \mathrm{ha}^{-1}$. With this treatment, hybrid NM 4467 achieved a yield more than $14 \mathrm{t} \mathrm{ha}^{-1}$.

At the $\mathrm{N} 120, \mathrm{P}_{2} \mathrm{O}_{5} 100, \mathrm{~K}_{2} \mathrm{O} 120 \mathrm{~kg} \mathrm{ha}^{-1}$ effective agent level, the yield in the average of the hybrids is $15.56 \mathrm{tha}^{-1}$, however, the yield of hybrid EM 5017 (FAO 530) is almost $20 \mathrm{t} \mathrm{ha}^{-1}$, and with enough water, its response to fertilizers is excellent. In terms of increase in the plant density, the hybrids had very different reactions. The optimum plant density of hybrid Renfor (FAO 320) is 70-75 thousand plants ha-1 with a lower yield level.

Hybrid EI 4411 (FAO 350) reacted the best: its yield kept increasing up to a plant density of 90 thousand plants per hectare, while hybrid NV 4467 (FAO 350) is highly sensitive to the higher plant density. Its yield significantly decreased above a plant density of 60 thousand plants ha-1 (Figure 5).

\section{Conclusion}

The productive capacity and the optimum sowing date of hybrids with different genetic backgrounds, and their response to fertilizers and the increase in plant density are very different. The correlation between the above mentioned agrotechnical factors and the yield are highly affected by the crop year, the amount of precipitation and its pattern in the growing season.

In a droughty year, the yield of the hybrids changed between 10 and $12 \mathrm{t} \mathrm{ha}^{-1}$ in the early sowing date with a plant density of 70 thousand plants per hectare, while the 85 thousand plants per hectare plant density caused yield depression. On the other hand, in the favourable crop year of 2016 the yield of the hybrids was 13.8-14.5 tha-1 with the 85 thousand plants per hectare plant density, due to the better water supply. 
Figure 5. The effect of increase in plant density on the yield of maize hybrids (Görbeháza, 2016)
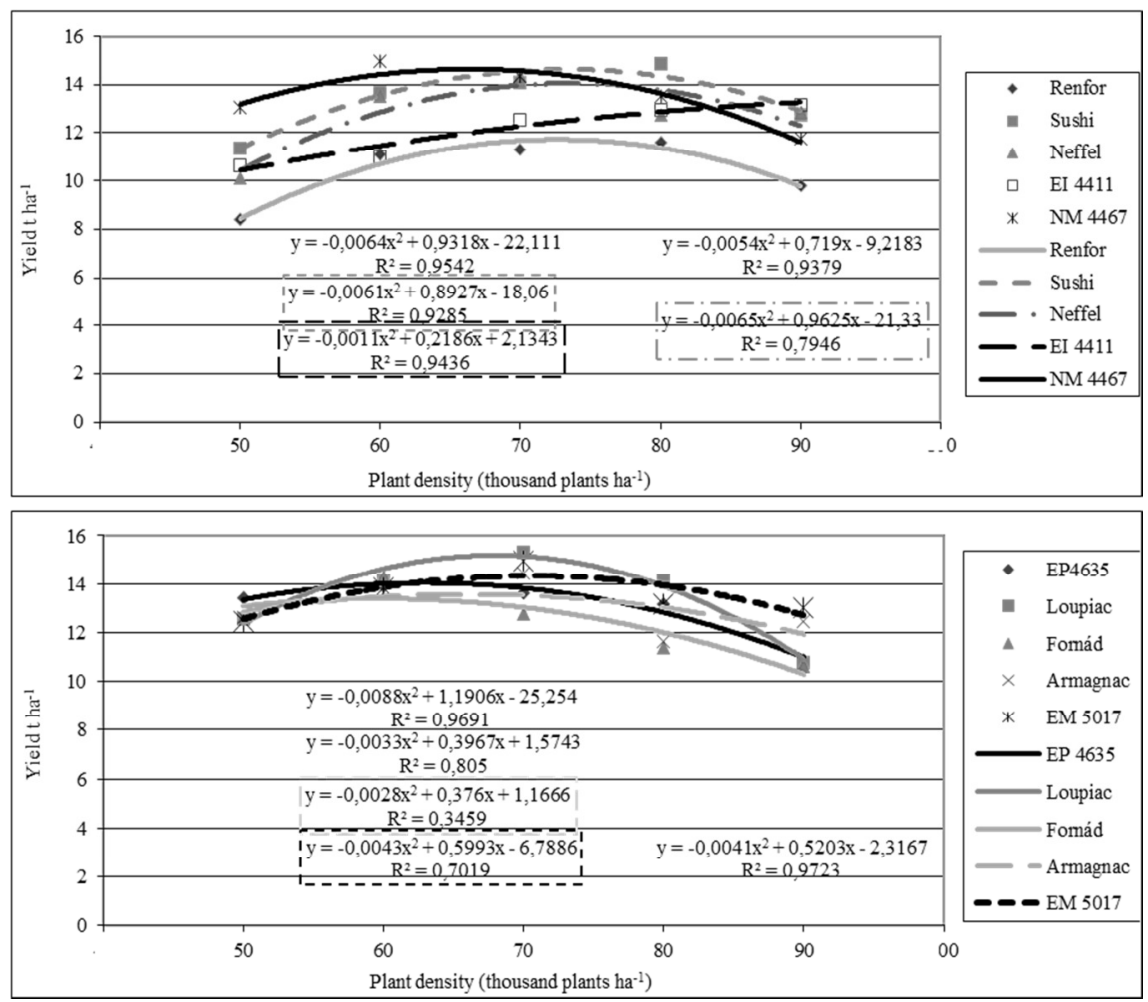

In a more favourable crop year, the sowing date has a slighter influence on the yield, and the hybrids achieved the higher yield with the 85 thousand plants ha-1. The results of the b type of experiment shows that the maximum yield of the tested hybrids changed between 9.18 and $12.59 \mathrm{t} \mathrm{ha}^{-1}$ with the 70 thousand plants per hectare plant density.

A close correlation could be detected between the growing season and the yield. Hybrids with longer growing seasons has a higher yield potential. Most of the hybrids achieved the maximum yield with the $\mathrm{N}$ $160+$ PK treatment, nevertheless, a treatment with such a high dosage of effective fertilizer agents cannot be recommended to be used in practice, because of efficiency and environmental aspects.

In a year with good water supply - like year 2016 -, the yield of hybrids, compared to the $\mathrm{N} 80, \mathrm{P}_{2} \mathrm{O}_{5} 50, \mathrm{~K}_{2} \mathrm{O} 60 \mathrm{~kg} \mathrm{ha}^{-1}$ fertilizer treatment, was significantly increased by the $\mathrm{N} 160, \mathrm{P}_{2} \mathrm{O}_{5} 100, \mathrm{~K}_{2} \mathrm{O} 120 \mathrm{~kg}$ ha $^{-1}$ fertilizer treatment. 
In order to improve yield stability, the application of modern agricultural techniques is essential, and a hybrid need to be selected that is appropriate for the given ecological conditions and has good adaptive ability.

\section{References}

Berzsenyi Z.-Györffy B. (1995): Különböző növénytermesztési tényező́k hatása a kukorica termésére és termésstabilitására. Növénytermelés. 44. 5-6: 507-517.

Berzsenyi Z.-Ragab, A. Y.-Lap, D. Q. (1998): A vetésidő hatása a kukoricahibridek (Zea mays L.) növekedési jellemzőire (a klasszikus és a HP-modell összehasonlítása). Növénytermelés. 47. 6: 655-676.

Berzsenyi Z.-Lap, D. Q. (2001): A vetésidó és a N-mútrágyázás hatása a kukorica(Zea mays L.) hibridek termésére és termésstabilitására 1991 és 2000 között. Növénytermelés. 50. 2-3: 309-331.

Bodnár E. (1992): A kukoricatermelés technológiája. Kukorica és Iparnövény Termelési Együttmúködés (KITE) kiadványa. Nádudvar.

Csajbók, J.-Kutasy, E.-Borbélyné, H. É.-Futó, Z.-Jakab, P. (2005): Effects of nutrient supply on the photosynthesis of maize hybrids. Cereal Res. Commun. 33. 1: 169-172.

Debreczeni B.-né (1994): A termőhely-klíma-talajtípus hatása főbb növényeink tápelem-koncentrációjára az OMTK kísérletekben. [In: Stefanovits P. (szerk.) Trágyázási kutatások 1960-1990. Akadémiai Kiadó. Budapest. 48-54.

Futó Z. (2003): A levélterület hatása a kukorica terméseredményére trágyázási kísérletben. Növénytermelés. 52. 3-4: 317-328.

Jakab P. (2003): A tápanyagellátás szerepe a hibridspecifikus kukoricatermesztésben. DE ATC MTK Növénytermesztési és Tájökológiai Tanszék. Doktori (PhD.) értekezés. Debrecen. 128.

Marton L. Cs.-Szundy T.-Hadi G.-Pintér J.-Berzsenyi Z.-Árendás T.-Bónis P. (2005). A termelői igényekhez igazodó kukoricanemesítés szempontjai Martonvásáron. Gyakorlati Agrofórum Extra. 9: 11-13.

Menyhért Z. (1985): A kukoricatermesztés kézikönyve. Mezőgazda Kiadó. Budapest. 560 .

Nagy J. (2010): Agrotechnikai tényezők hatása a kukorica termésére. [In. Pepó P. (szerk.) Termesztési tényezők a fenntartható növénytermesztésben.] DE AGTC Kiadvány. Debrecen. 160-167.

Pepó P.-Sárvári M. (2011): Gabonanövények termesztése. Debreceni EgyetemNyugat-Magyarországi Egyetem-Pannon Egyetem. Agrármérnöki MSc szak tananyagfejlesztése. TÁMOP-4.1.2-08/1/A-2009-0010 projekt. www.tankonyv tar.hu

Pepó, P.-Vad, A.-Berényi, S. (2006): Effect of some agroteczniical elements on the yield of maize on chernozem soil. Cereal Res. Commun.. 34. 1: 621-624.

Pepó, P.-Pepó, P. (1993): Biological background of sustainable maize (Zea mays L.) production. Landscape and Urban Planning. 179-184. 
Sárvári M. (1999): Ökológiai tényezők hatása az eltérő genetikai adottságú kukoricahibridek termésére és minóségére. [In: Ruzsányi L. et al. (szerk.) Tiszántúli Mezőgazdasági Tudományos Napok.] DATE. Debrecen. 97-103.

Széles A.-Nagy J. (2013): A hazai kukorica minősége. Debreceni Szemle Tudomány és Kultúra. Debrecen és a régió tudományos múhelyeinek folyóirata. 12. 4: 204-210. 